\title{
Perennial grass establishment in relationship to seeding dates in the Northern Great Plains
}

\author{
R.E. RIES AND L. HOFMANN
}

Authors are range scientist and research agronomist (retired), USDA-ARS, Northern Great Plains Research Laboratory, P.O. Box 459, Mandan, N.D. 58554.

\begin{abstract}
A 3-year field study with 5 species and 11 seeding dates per year was conducted to determine which dates resulted in successful stands when directly seeded into wheat stubble at each seeding date at Mandan, N.D. There was considerable range in the monthly highs and lows for many of the environmental parameters collected during this study. Significant seeding date $X$ year interactions occurred due to changes in environmental conditions at each repeated seeding date. This indicates that while certain seeding dates during the year can be expected to provide good grass establishment because of cooler temperatures and more precipitation, failures can also occur at any seeding date when the expected favorable weather conditions fail to materialize. Stands were successful when the stems $\mathrm{m}^{-2}$ were equal to or greater than the stems expected from 11 plants $\mathrm{m}^{-2}$. Successful stands occurred $64,58,61,52$, and $45 \%$ of the time for smooth bromegrass (Bromus inermis Leyss., 'Lincoln'), western wheatgrass [Agropyron smithii Rydb., 'Rodan'; syn.=Pascopyron smithii (Rydb.) Löve], crested wheatgrass [Agropyron desertorum (Fisch.) Schult., 'Nordan'], sideoats grama [Bouteloua curtipendula (Michx.) Torr., 'Pierre'], and blue grama (Bouteloua gracilis (H. B. K.) Lag ex Steud., native collection], respectively. The significant seeding date $\times$ year interaction indicated established seedling stems $\mathrm{m}^{-2}$ varied greatly at the same seeding date in different years. This interaction explains why individuals favor different seeding dates based on their past experience. Successful seeding dates are summarized, but failures can occur at any specific date in a given year.
\end{abstract}

Key Words: smooth bromegrass, sideoats grama, western wheatgrass, blue grama, crested wheatgrass.

Moser and Newman (1988) support the premise that the best time to seed dryland grasses is immediately prior to a long wet spell. There is no validated method for predicting the onset of a long wet spell in the Great Plains. Most research concerning seeding dates has been done on a date of month or season basis. Hull (1948) found seeding grass in the fall was more successful

\footnotetext{
Authors would like to thank Mr. Gordon A. Jensen and Mr. Curtis A. Klein for technical assistance.

This article is a contribution from USDA-ARS, Mandan, North Dakota. USDAARS, Northem Plains Area, is an equal opportunity/affirmative action employer and all agency services are available without discrimination.

Manuscript accepted 20 Dec. 1995.
}

than spring seedings in Idaho for cool-season grass species, but March seedings were successful if the area had a long spring growing season.

McWilliams (1955) reported the results from a 7-year seeding date study where seedings were made into a uniform 20 to $25 \mathrm{~cm}$ (8-10 in) wheat stubble seedbed in North Dakota several times each year. Cool-season grasses established best when seeded in September or October. Warm-season grasses established best when seeded in April or May when no fall seeding dates were included in the study.

McGinnies (1960) found that satisfactory stands of crested wheatgrass and smooth bromegrass could be obtained by planting during any month from April to November. Only 1 April plantings gave consistently acceptable stands. All other dates resulted in failure or a poor stand in at least 1 year of the 4 year study period. In southern Saskatchewan, intermediate wheatgrass [Agropyron intermedium (Host) Beauv.; syn.=Thinopyrum intermedium (Host) Barkworth D.R. Dewey]; and Russian wildrye [Elymus junceus Fisch.; syn.= Psathyrostachys juncea (Fischer) Nevski] gave better results from spring seedings with some success from late fall seeding (Kilcher 1961). Crested wheatgrass and green needlegrass (Stipa viridula Trin.) displayed better seedling stands from fall plantings. Streambank wheatgrass [Agropyron riparium Scribn. and Smith; syn.=Elymus lanceolatus (Scribner J.G. Smith) Gould] had the widest range of successful seeding dates.

Lodge and Schipp (1993) recently reported that the most successful field establishments of wallaby grasses (Danthonia richardsonii Cashmore and Danthonia linkii Kunth) in Australia occurred from surface sowing in April and May. Sowing in the spring in Australia may also be possible if mean maximum soil temperatures exceed $23^{\circ} \mathrm{C}$, and seedlings can establish before the onset of hot, dry conditions in summer.

McGinnies (1973) noted that the same seeding date did not establish the same stand each year because of great environmental variations from year-to-year. This indicates a significant seeding date $\times$ year interaction; but, it was not graphically presented or evaluated. Little information or data are available in the literature evaluating seeding date $x$ year interactions; however, understanding this interaction may explain why great variation in grass stand success from similar seeding dates in different years can and will occur.

The present study was conducted to evaluate the establishment of 5 forage grass species over a wide range of seeding dates during a 3-year period using the same seeding practices for all seeding dates and to answer the following questions: 1) How much do environmental conditions vary from year to year and what effect 
does this have on grass establishment; 2) What establishment level can be expected for various grass species across years; and 3) What is the best seeding date for a certain species across years?

\section{Study Area and Methods}

This study was conducted at the Northern Great Plains Research Laboratory, Mandan, N.D. Soils of the study area are a Parshall fine sandy loam (coarse-loamy, mixed Pachic Haploborolls). Spring wheat was grown in $17.8-\mathrm{cm}$ rows and harvested each year prior to seeding grass. Grass was seeded in 15$\mathrm{cm}$ rows directly into 35 to $40 \mathrm{~cm}$ tall stubble perpendicular to the stubble rows with a cone seeder (Barker et al. 1976). A cone seeder with double disk openers, depth bands, and packer wheels was used to seed all species at a rate of $9 \mathrm{~kg} \mathrm{ha}^{-1}$ pure live seed at a depth of about $13 \mathrm{~mm}$. Seeding years were 1986-87, 1987-88, and 1988-89. Eleven seeding dates were used each year; 15 August, 4 and 24 September, 9 October, 1 November, 1 and 21 April, 9 and 26 May, 10 June, and 1 July.

Five forage grass species were seeded at each seeding date. These included 3 cool-season grasses; smooth bromegrass, western and crested wheatgrass, and 2 warm-season grasses; sideoats and blue grama. Broadleaf weeds were controlled with Brominal, Buctril and LV4 2, 4- $\mathrm{D}^{1}$ after the grass seedlings were mature enough.

Plots ( $3 \mathrm{~m}$ wide and $7.6 \mathrm{~m}$ long) were arranged in a randomized complete block design, split/split plot in time with 3 replications. Whole plots were years, the first split was species and the final split was seeding date.
Environmental conditions during the study were monitored by a weather station located on the study areas following National Weather Bureau standards. Parameters measured included air temperature at $2 \mathrm{~m}$ above the soil, soil temperature at $16 \mathrm{~mm}$-soil depth, precipitation, and free water evaporation from a Class $\mathrm{A}$ pan. Soil water in the top $7.6 \mathrm{~cm}$ of soil was measured gravimetrically. Whole profile soil water was measured with soil neutron meters through access tubes to a depth of $1.8 \mathrm{~m}$. Weather data were summarized monthly.

Since species did not respond the same, data were analyzed by species. Years and seedling dates were analyzed by Analysis of Variance (SAS Institute 1990). Because of a significant seeding date $X$ year interaction, data were analyzed and interpreted within years. Significant mean differences in seeding date stem density were separated within each seeding year by Tukey's HSD test at $P \leq 0.05$ using Tukey's HSD based on 3 years. To visualize the seeding date $X$ year interactions, stem density means for each species were graphed for each seeding date over the 3 year study. To evaluate seeding dates for each species, we compared stem density expected from 11 plants $\mathrm{m}^{-2}$ considered as a measure of a successful grass stand by the Great Plains Council (1966).

\section{Results and Discussion}

Weather and soil environmental data collected during this study show considerable variation in observed monthly highs and lows (Tables 1-3). The highest mean air temperature occurred in June of 1988 (Table 1). Spring seeding date temperatures were generally higher than the long-term average. Mean soil temperatures at a depth of $16 \mathrm{~mm}$ exceeded the mean air temperatures with about

Table 1. Mean air and soil temperatures during seeding date study, 1986-1991.

\begin{tabular}{|c|c|c|c|c|c|c|c|c|c|c|c|c|c|c|}
\hline \multirow{2}{*}{ Month } & \multicolumn{6}{|c|}{ Mean Air Temp. at 2m } & \multicolumn{8}{|c|}{ Mean Soil Temp. at $16 \mathrm{~mm}$} \\
\hline & '86 & ‘87 & ' 88 & 89 & 90 & '91 & LTA $^{1}$ & '86 & 87 & '88 & 89 & ‘9 & ‘91 & AVG. $^{2}$ \\
\hline & & & & & & & $-(C$ & & & $\ldots$ & - & - - - - - & - . & - \\
\hline Aug. & 18.1 & 17.5 & 20.5 & 20.6 & 21.6 & 一 & 20.4 & 20.4 & 20.6 & 23.3 & 24.8 & 25.8 & - & 23.2 \\
\hline Oct. & 6.7 & 5.4 & 6.7 & 7.2 & 6.8 & - & 7.8 & 7.1 & 6.7 & 7.9 & 8.8 & 7.6 & - & 7.6 \\
\hline Nov. & -4.5 & 1.6 & -0.9 & -1.4 & -0.1 & 一 & -1.8 & 1.2 & 1.9 & 0.1 & -0.7 & 0.1 & 一 & 0.5 \\
\hline Dec. & -4.9 & -4.4 & -6.3 & -11.9 & -10.6 & - & -9.2 & -2.1 & -3.6 & -4.8 & -9.2 & -7.0 & - & -5.3 \\
\hline Jan. & - & -5.2 & -11.6 & -7.7 & -4.7 & -10.9 & -14.1 & - & -4.2 & -8.4 & -4.5 & -4.8 & -9.1 & -6.2 \\
\hline Apr. & - & 10.5 & 7.8 & 6.4 & 6.3 & 7.8 & 5.3 & - & 11.8 & 11.2 & 9.2 & 10.0 & 9.4 & 10.3 \\
\hline May & - & 13.3 & 16.0 & 13.7 & 13.2 & 14.5 & 12.5 & - & 18.0 & 18.9 & 17.0 & 17.0 & 16.4 & 17.5 \\
\hline Jun. & - & 19.7 & 24.9 & 17.8 & 18.5 & 19.4 & 17.8 & - & 23.8 & 30.3 & 20.8 & 21.7 & 21.8 & 23.7 \\
\hline Jul. & - & 21.4 & 22.9 & 24.3 & 20.8 & 21.6 & 21.2 & - & 23.7 & 27.0 & 29.2 & 24.2 & 23.7 & 25.6 \\
\hline
\end{tabular}

${ }_{\text {LTA }=\text { long term average }-78 \text { years. }}$

${ }^{2}$ Five year average.

Grass stands were clipped to a $25 \mathrm{~cm}$ stubble height each fall and to a stubble height of $5-7 \mathrm{~cm}$ in the spring prior to initiation of growth to reduce seasonal carryover litter. Grass stands were sampled during the summer 2 years after seeding at near peak biomass accumulation. At this time the stem density (stems $\mathrm{m}^{-2}$ ) was counted on 5 randomly located 30.5 by $30.5 \mathrm{~cm}$ plots for each species and seeding date.

${ }^{\mathrm{T}}$ Use of trade names does not signify endorsement of these herbicides. the same range in values for each month. The amount of precipitation and free-water evaporation varied greatly throughout the 3years of study (Table 2). Soil water content at seeding depth (13-25 mm) was the highest and lowest during the 1986-87 seeding year (Table 3). These differences in the weather and soil conditions at each repeated seeding date in different years is believed to have resulted in a significant seeding date $x$ year interaction (Figs. 1-5). 


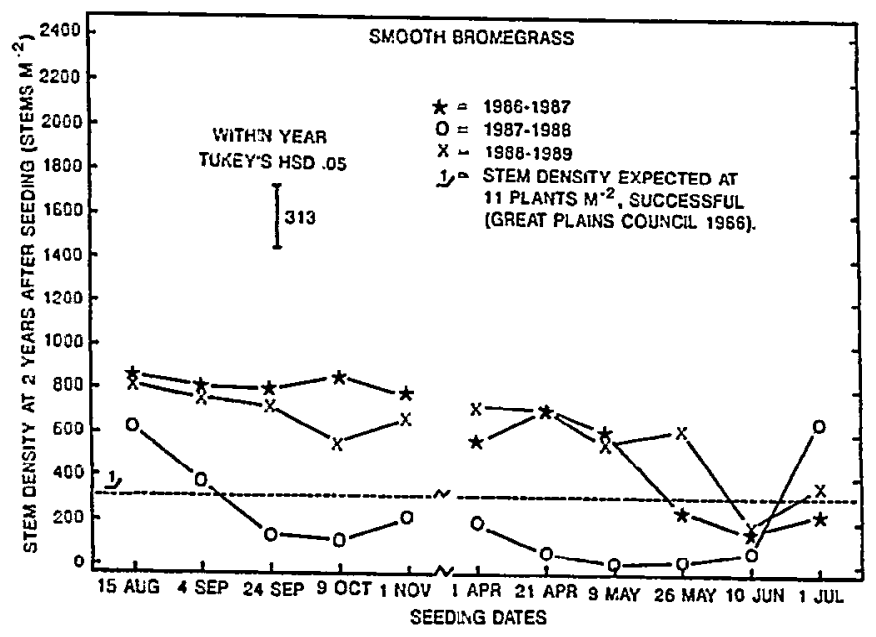

Fig. 1. Grass stand densities at 2 years after seeding show significant seeding date $X$ year interaction for smooth bromegrass.

Stem densities fluctuated greatly for any given seeding date in any seeding year. This indicates that while a certain seeding date during the year can be expected to provide for good grass establishment because weather conditions are usually favorable, failures can also be expected at any seeding date when the expected favorable weather conditions fail to materialize. The important factor to successful seeding is not the date as much as the actual weather and soil conditions that occur after seeding.

The stem density expected for 11 plants of smooth bromegrass was $304 \mathrm{~m}^{-2}$ (Great Plains Council 1966). Twenty-one stands out of $33(64 \%)$ had the expected stem densities or more at 2 years after seeding. At least 3 stands had 304 or more stems $\mathrm{m}^{-2}$ each seeding year. The 1988-89 seeding year had 10 dates equal to or above this standard. The 15 August and 4 September seeding dates produced stands with the standard density all 3 years (Fig. 1).

Western wheatgrass had an expected stem density of $476 \mathrm{~m}^{-2}$ for 11 plants (Great Plains Council 1966). During the 1988-89 seeding year, 9 seeding dates had 476 or more stems. Overall, 19 of the 33 seedings (58\%) of western wheatgrass were 476 stems

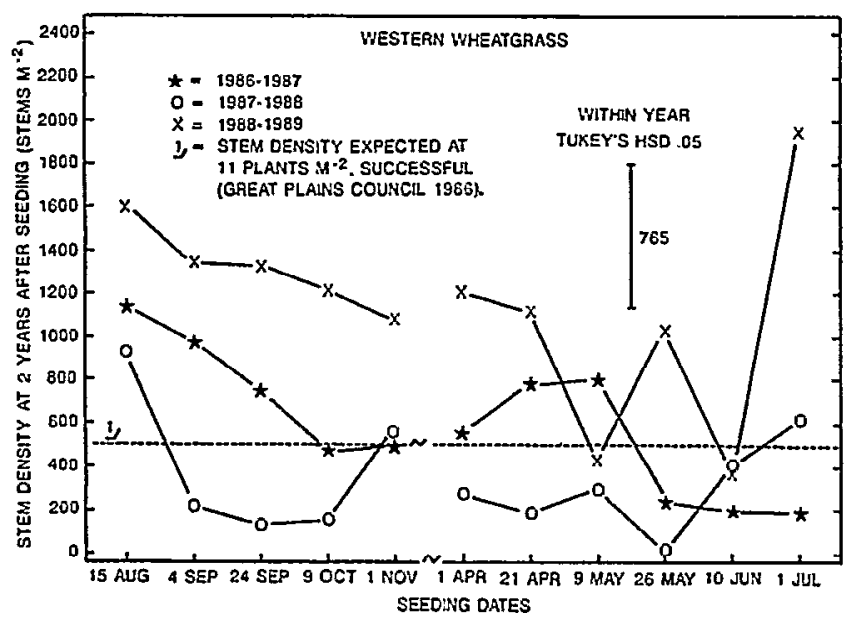

Fig. 2. Grass stand densities at 2 years after seeding showing significant seeding date $X$ year interaction for western wheatgrass.

$\mathrm{m}^{-2}$ or above. The 15 August and 1 November seeding dates had $476 \mathrm{stems} \mathrm{m}^{-2}$ or above for all 3 years of the study (Fig. 2).

Crested wheatgrass had the greatest expected numerical stem density ( 590 stems $\mathrm{m}^{-2} 2$ years after seeding) for 11 plants (Great Plains Council 1966). Three seeding dates had 590 stems $\mathrm{m}^{-2}$ or above during the 1987-88 seeding year, while 1988-89 had 9 seeding dates producing stands with 590 stems $\mathrm{m}^{-2}$ or more. Crested wheatgrass established stands with $590 \mathrm{stems} \mathrm{m}^{-2}$ or more a total of 20 seeding dates out of the $33(61 \%)$. When seeded on 15 August and 4 September, crested wheatgrass stands had 590 stems $\mathrm{m}^{-2}$ or more established all 3 years (Fig. 3). McWilliams (1955) reported crested wheatgrass stands seeded in September produced the best stands and he did not study a 15 August date.

Sideoats grama stands had an expected 201 stems $\mathrm{m}^{-2}$ for 11 plants (Great Plains Council 1966). Seventeen seeding dates out of the $33(52 \%)$ resulted in stands with the success standard stem densities. At least 4 seeding dates in each seeding year produced 201 or more stems $\mathrm{m}^{-2}$ and in the 1986-87 seeding year, 7 seeding dates produced 201 or more stems. Sideoats grama stands with 201 or more stems occurred 3 out of the 3 years at 1 April and 9 May seeding dates (Fig. 4).

Table 2. Mean precipitation and free water pan evaporation during seeding date study, 1986-1991.

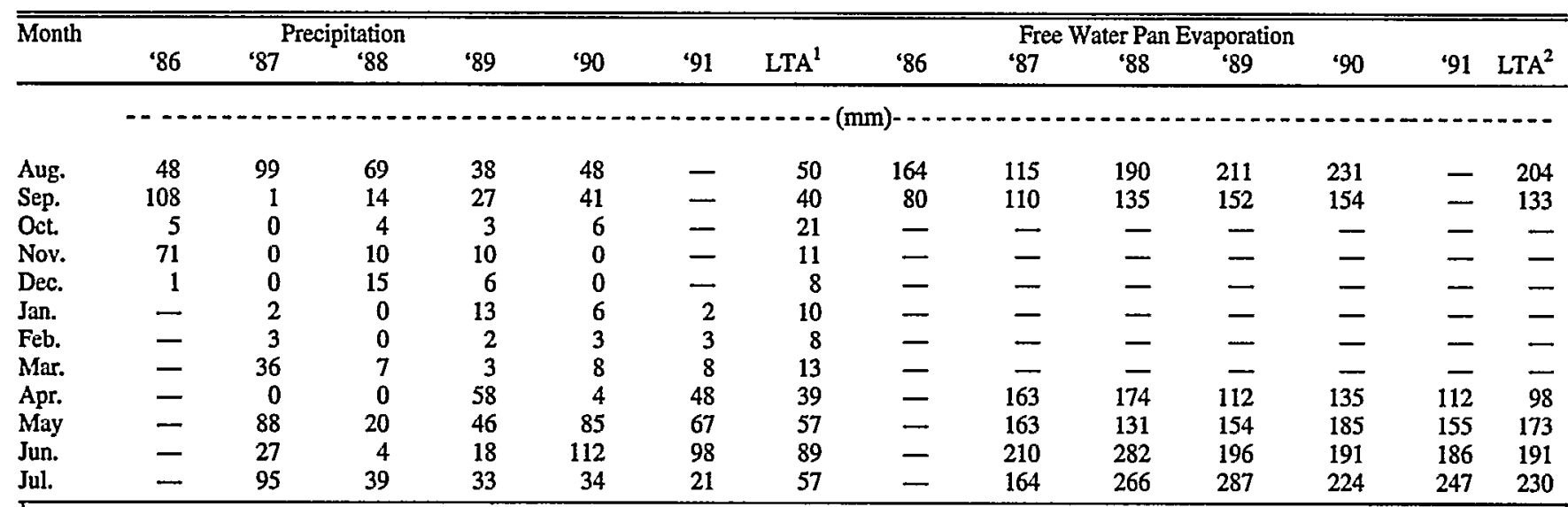

LTA=long term average-78 years.

${ }^{2}$ LTA=long term average-20 years. 
Table 3. Mean soil water content during grass seeding date study, 1986-1991.

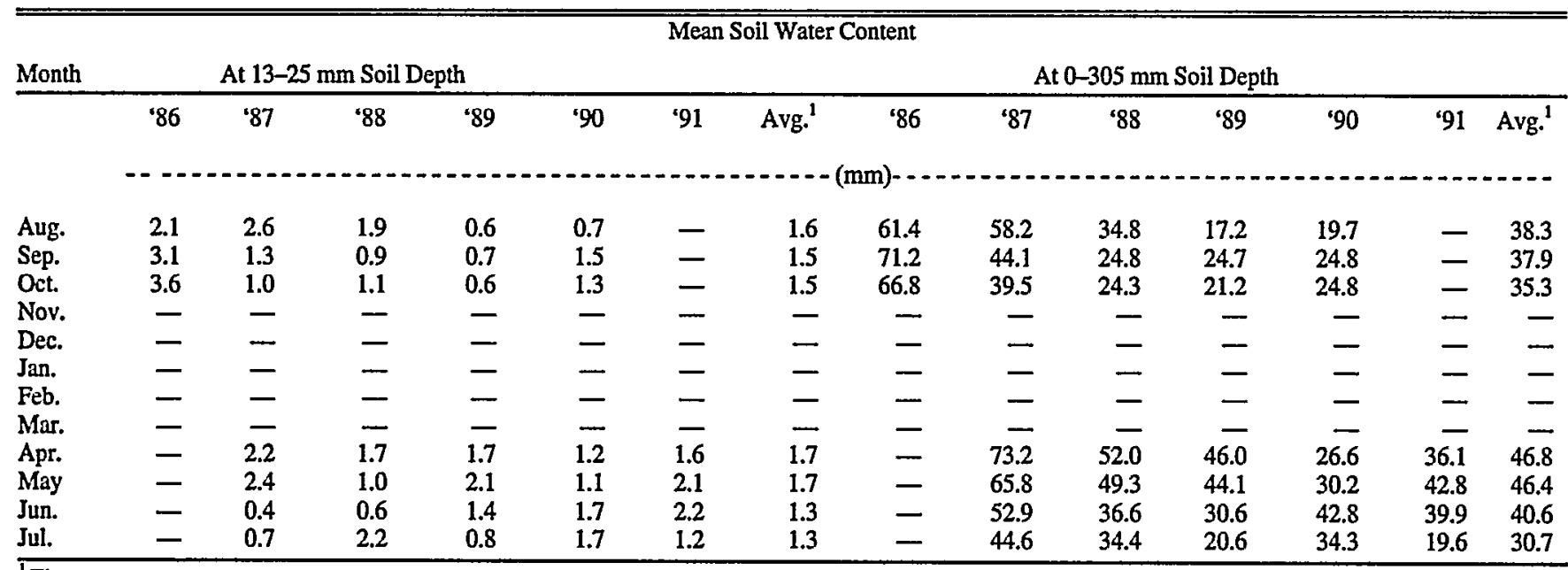

${ }^{1}$ Five year average.

Eleven blue grama plants had an expected stem density of 429 $\mathrm{m}^{-2}$ (Great Plains Council 1966). Fifteen out of 33 (45\%) of the seeding dates resulted in blue grama stands with 429 stems m$~ m^{-2}$ or more. Four seeding dates had the standard or more stems in 1988-89 and 6 dates had 429 or more stems in 1986-87. Seeding dates of 1 November, 21 April, and 9 May produced stands with 429 or more stems in all 3 years (Fig. 5). McWilliams (1955) found blue grama stands seeded 20 April and 10 May produced the most successful stands and he did not try to seed warm-season grasses in the fall.

\section{Conclusions}

Environmental conditions varied greatly throughout the study (Tables 1-3). The monthly weather data presented needs to be on a shorter time frame to better relate to specific seeding date outcomes. Seeding dates when temperatures are near average and precipitation is average or above are most likely to be successful. While a certain seeding date can be expected to be best for seed-

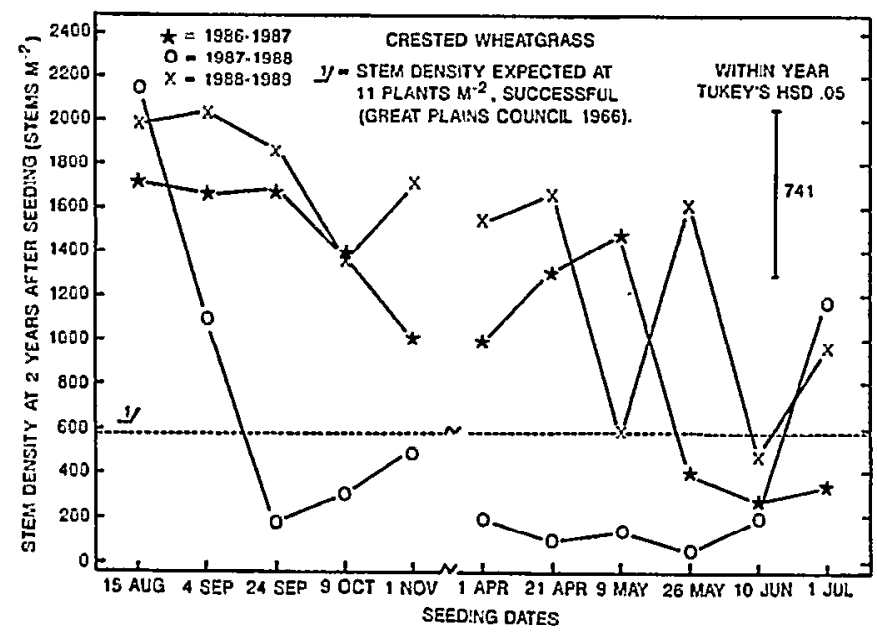

Fig. 3. Grass stand densities at 2 years after seeding showing significant seeding date $X$ year interaction for crested wheatgrass. ing because of expected favorable environmental conditions, e.g., lower temperatures and more precipitation, failures at the same date can be expected when environmental conditions favorable to grass establishment do not materialize. Actual weather and soil conditions that develop after a grass seeding are more important than the seeding date. Differing environmental conditions at the same seeding date in different seeding years are the most likely cause of the significant seeding date $X$ year interaction.

Stands with the number of stems $\mathrm{m}^{-2}$ expected from 11 plants $\mathrm{m}^{-2}$ (Great Plains Council 1966) (successful stands) occurred 64, $58,61,52$, and $45 \%$ of the time for smooth bromegrass, western wheatgrass, crested wheatgrass, sideoats grama, and blue grama, respectively. The stem densities observed in the study varied greatly (Figs. 1-5).

The most significant finding of the study is the significant seeding date $X$ year interaction. This interaction presented graphically in Figs. 1-5 shows greatly different seedling numbers from the same seeding date in different seeding years. In other words, the successful seeding dates were not consistent across the years.

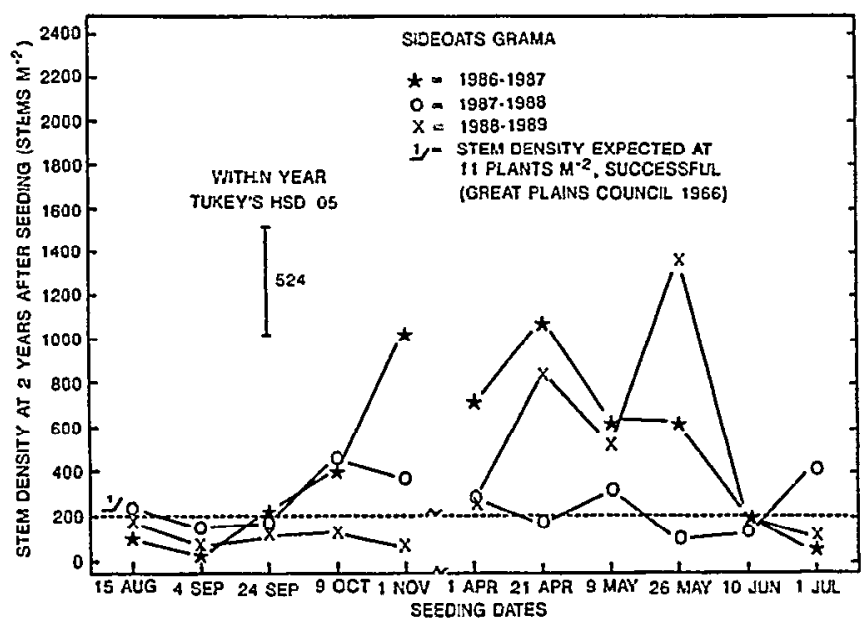

Fig. 4. Grass stand densities at 2 years after seeding showing significant seeding date $X$ year interaction for sideoats grama. 


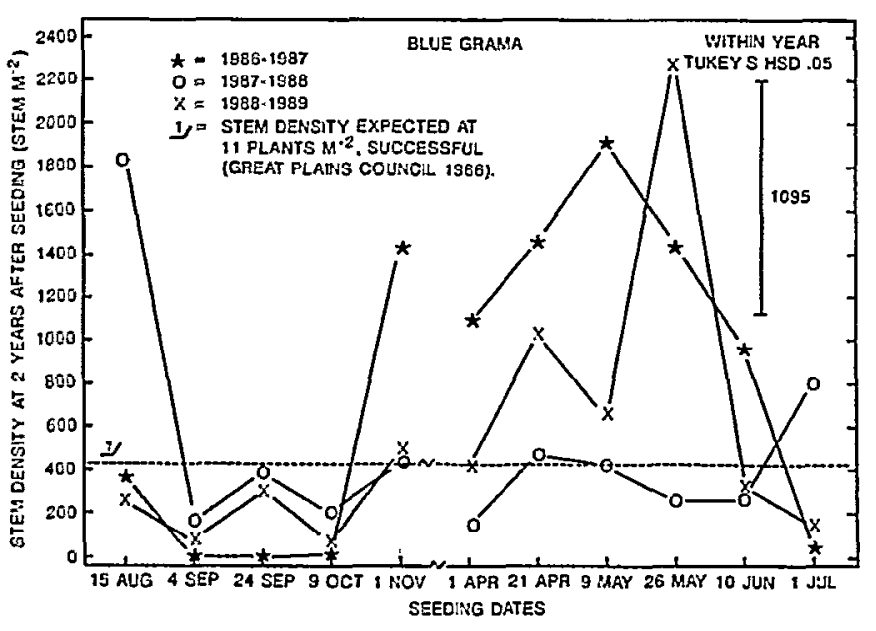

Fig. 5. Grass stand densities at 2 years after seeding showing significant seeding date $X$ year interaction for blue grama.

Like reports of past seeding date studies, the most successful seeding dates can be identified (Figs. 1-5): however, failures in establishment of these species can be expected at any of these dates periodically.

A summary of the most successful seeding dates shows 15 August was successful for establishing smooth bromegrass, western wheatgrass, and crested wheatgrass all 3 years of the study. Little previous data concerning the use of an August date for seeding grasses in the northern Great Plains can be found in the literature. Western wheatgrass was also successfully established each year of the study when seeded 1 November. Successful stands of smooth bromegrass and crested wheatgrass were established by seeding on 4 September each year of the study and McWilliams (1955) reported similar results. Successful seeding dates observed for sideoats in the study were 1 April and 9 May all 3 years of the study. Successful stands of blue grama were produced 3 out of 3 years when seeded 1 November, 21 April, and 9 May. McWilliams (1955) did not seed sideoats and blue grama in the fall and reported that 20 April and 10 May produced the best stands of these species from his study. Results of this study fit well with the conventional experience of grass seedings in that cool-season species established best in fall and warm-season species established best in late winter to mid-spring. These dates can be used when planning for the best time to seed smooth bromegrass, western wheatgrass, crested wheatgrass, sideoats grama, and blue grama; however, failures in establishing these species at these dates in any specific year can occur because of unfavorable environmental conditions.

\section{Literature Cited}

Barker, R.E., J.J. Bond, and L.G. Zachmeier. 1976. Equipment for seeding experimental plots of small grains, grasses, and legumes. Agron. J. 68:141-142.

Great Plains Council. 1966. A stand establishment survey of grass plantings in the Great Plains. University of Nebraska, Agricultural Experiment Station. Report No. 23, 60 p.

Hull, A.C., Jr. 1948. Depth, season, and row spacing for planting grasses on southern Idaho range lands. J. Amer. Soc. Agron. 40:960-969.
Kilcher, M.R. 1961. Fall seeding vs spring seeding in the establishment of five grasses and one alfalfa in southern Saskatchewan. J. Range Manage. 14:320-322.

Lodge, G.M. and A.J. Schipp. 1993. Effects of depth and time of sowing on emergence of Danthonia richardsonii Cashmore and Danthonia linkii Kunth. Aust. J. Agr. Res. 44:1311-1322.

McGinnies, W.J. 1960. Effects of planting dates, seeding rates, and row spacings on range seeding results in western Colorado. J. Range Manage. 13:37-39.

McGinnies, W.J. 1973. Effects of date and depth of planting on the establishment of 3 range grasses. Agron. J. 65:120-123.

McWilliams, J.L. 1955. Effect of some cultural practices on grass production at Mandan, North Dakota. Tech. Bul. No. 1097. USDA, Washington, D.C.

Moser, L.E. and P.R. Newman. 1988. Grass seedling development. In: Proceedings: Northern Plains Grass Seed Symposium. (January 7-8, 1988). Pierre, S.D.

SAS Institute. 1990. SAS User's Guide, Version 6, Vol. 1 \& 2. Cary, N.C. 